\title{
PENERAPAN APLIKASI WHATSAPP TERHADAP MINAT DAN PRESTASI PESERTA DIDIK
}

\author{
Devi Ratnasari ${ }^{1)}$, Ponoharjo ${ }^{2)}$, Wikan Budi Utami ${ }^{3)}$ \\ ${ }^{1), 2), 3)}$ Program Studi Pendidikan Matematika, FKIP, Universitas Pancasakti Tegal, Indonesia \\ rdevi2952.dr@gmail.com ; ponoharjo@gmail.com ; wikan.piti@gmail.com
}

\begin{abstract}
This study aims to examine the interests and achievements of students who are thought using the Whatsapp application with better material than students who are taught using the Whatsapp application without material. The research carried out is experimental research. The population in this srudy were all class X TKRO SMK Negeri 2 Slawi. While the sample was taken from two classes, namely class X TKRO 1 being the experimental class and class X TKRO 2 being the control class. The instrument used in this study were 20 questionnaire items and 10 multiple-choice test questions that measured students interest and learning achievement. The way to know the interest and learning achievement is better, then previously the sample eduivalence test was carried out using the one-way analysis of variance test. Then the post-test performance data were processed using the univariate and multivariate normality test, the univariate and multivariate homogeneity tests and the $\tau 2$-Hotelling test. Based on the analysis of the result of data processing in this study, it can be concluded that the interest ang achievement of mathematics learning students who are taught using the Whatsapp application with material is better than students who are taught using the Whatsapp application whitout material.
\end{abstract}

Keywords: Whatsapp application, interest, learning achievement

\begin{abstract}
Abstrak
Penelitian ini bertujuan untuk mengkaji Minat dan prestasi belajar matematika peserta didik yang diajar menggunakan aplikasi Whatsapp dengan materi lebih baik daripada peserta didik yang diajar menggunakan aplikasi Whatsapp tanpa materi. Penelitian yang dilaksanakan yaitu penelitian eksperimen . populasi dalam penelitian ini yaitu seluruh kelas X TKRO SMK Negeri 2 Slawi. Sedangkan sampelnya diambil dua kelas, yaitu kelas X TKRO 1 menjadi kelas eksperimen dan kelas $\mathrm{X}$ TKRO 2 menjadi kelas kontrol. Instrumen dalam penelitian adalah 20 item angket dan 10 soal tes berbentuk pilihan ganda yang mengukur minat dan Prestasi belajar peserta didik. Cara mengetahui minat dan Prestasi belajar itu lebih baik maka sebelumnya dilakukan uji kesetaraan sampel yaitu menggunakan uji analisis ragam satu arah. Kemudian data Prestasi postes diolah dengan dengan langkah uji normalitas univariat dan multivariat, uji homogenitas univariat dan multivariat dan uji $\tau 2$ Hotelling. Berdasarkan analisis hasil pengolahan data pada penelitian ini, disimpulkan bahwa Minat dan Prestasi belajar matematika peserta didik yang diajar menggunakan aplikasi Whatsapp dengan materi lebih baik daripada peserta didik yang diajar menggunakan aplikasi Whatsapp tanpa materi.
\end{abstract}

Kata Kunci : Aplikasi Whatsapp, Minat,Prestasi Belajar

Cara Menulis Sitasi: Ratnasari, D., Ponoharjo, Utami, W., B. (2020). Penerapan aplikasi whatsapp terhadap minat dan prestasi peserta diddik. Jurnal Edukasi dan Sains Matematika (JES-MAT), 6 (2), 129-138. 


\section{PENDAHULUAN}

Menurut Syah (2006) secara garis besar faktor-faktor yang mempengaruhi hasil belajar dapat dibedakan menjadi tiga macam, yakni: 1) Faktor internal (faktor dari dalam diri peserta didik), yakni keadaan/kondisi jasmani dan rohani peserta didik. 2) Faktor eksternal (faktor dari luar peserta didik), yakni kondisi lingkungan di sekitar peserta didik. 3) Faktor pendekatan belajar (approach to learning), yakni jenis upaya belajar peserta didik yang meliputi metode dan metode yang digunakan peserta didik untuk melakukan kegiatan pembelajaran materi-materi pelajaran.

Salah satu faktor yang menghambat Prestasi belajar matematika peserta didik adalah cara mengajar guru dalam proses belajar mengajar yang kurang menarik sehingga menimbulkan rasa bosan serta enggan bagi peserta didik. Dimana guru cenderung lebih mendominasi pembelajaran, dan peserta didik hanya diberikan tugas-tugas saja oleh guru. Sehingga pembelajaran cenderung monoton yang hanya terpaku pada buku paket serta pembelajaran masih mengarah pada satu arah saja yang menyebabkan minat peserta didik cenderung kurang. Salah satu dampak dari kurangnya minat peserta didik dalam belajar akan menimbulkan pemahaman yang rendah terhadap materi matematika.

Suatu pemahaman diperoleh peserta didik melalui suatu rangkaian proses yang dilalui oleh peserta didik saat belajar dan berinteraksi dengan orang lain, sehingga peserta didik dapat membentuk pengetahuan dan pemahaman yang dialaminya. Oleh karenanya dalam proses pembelajaran matematika guru dituntut mampu memilih metode, strategi ataupun model pembelajaran yang tepat dalam menyampaikan materi pembelajaran, sehingga tujuan dan harapan pembelajaran dapat terwujud dengan baik. (Siagian, 2015)

Sekolah Menengah Kejuruan (SMK) Negeri 2 Slawi merupakan sekolah yang menerapkan Kurikulum 2013 sehingga model pembelajaran yaitu pembelajaran kooperatif. Berdasarkan hasil observasi bahwa sebagian peserta didik bersikap acuh, kurang berminat mempelajari matematika terutama untuk membaca materi yang dipelajari dan masih suka bermain dengan teman lainnya sehingga kurang memperhatikan pembelajaran. oleh karena itu, dalam proses pembelajarannya terkadang guru masih menggunakan model pembelajaran Konvensional dan Tanya jawab. Dan ketika diberikan latihan soal maka guru harus menunjuk peserta didik untuk mengerjakan ke depan karena dengan begitu mau mengerjakan latihan soal yang diberikan dan hanya beberapa peserta didik yang mau maju untuk menyelesaikan soal, dan guru juga mengatakan bahwa peserta didik harus dimotivasi terus menerus untuk menumbuhkan rasa minat peserta didik.

Slameto (2010) menyatakan bahwa minat adalah suatu rasa lebih suka dan rasa keterikatan pada suatu hal atau aktifitas, tanpa ada yang menyuruh. Dengan demikian pernyataan guru matematika SMK Negeri 2 Slawi yang menyatakan bahwa siswa harus ditunjuk untuk maju ke depan agar mau mengerjakan soal yang diberikan, dan peserta didik juga harus selalu dimotivasi terus menerus hal tersebut dapat dikatakan bahwa minat peserta didik dalam mempelajari matematika rendah.

Dengan adanya Pandemi Corona Virus Disease 2019 atau yang sering disebut Covid-19 maka semua sekolah- 
sekolah yang ada di Indonesia diberlakukan metode pembelajaran yang awalnya metode pembelajaran tatap muka diganti menggunakan metode pembelajaran online seperti Whatsapp, Google Classroom dan lain sebagainya. Termasuk SMK N 2 Slawi juga menggunakan metode pembelajaran online yaitu menggunakan aplikasi Whatsapp.

Hasil penelitian sebelumnya yang dilakukan oleh Utomo dkk. (2018) menyatakan bahwa pemanfaatan aplikasi Whatsapp dengan model pembelajaran berbasis masalah adalah kemudahan dalam menyebarkan materi perkuliahan, berkomunikasi, berdiskusi, dan melalui kemudahan yang sedemikian ini, hasil belajar mahasiswa meningkat. Hasil penelitian lainya yang dilakukan oleh Ningrum \& Pramonojati (2019) menyatakan penggunaan Whatsapp yang dilakukan oleh pegawai Dinas Pariwisata DIY mempengaruhi efektivitas komunikasi organisasi yang positif. Kebaruan penelitian ini adalah penelitian tentang penerapan aplikasi Whatsapp terhadap minat dan prestasi belajar peserta didik di sekolah menengah kejuruan.

\section{LANDASAN/KAJIAN TEORI E-Learning}

Menurut Hanum (2013) E-learning merupakan bentuk model pembelajaran yang difasilitasi dan didukung pemanfaatan teknologi informasi dan komunikasi. Sedangkan menurut Mulyati (2017) Elearning adalah suatu jenis belajar mengajar yang memungkinkan tersampaikannya materi pembelajaran ke peserta didik dengan menggunakan media internet, intranet dan media jaringan komputer lain.
Menurut Clark \& Mayer (2008) Ciriciri E-Learning yaitu : 1) memiliki konten yang relevan dengan tujuan pembelajaran. 2) menggunakan metode instruksional, seperti penyajian contoh, latihan untuk meningkatkan pembelajaran. menggunakan komponen media seperti kata-kata dan gambar untuk menyampaikan materi pembelajaran. 4) memungkinkan pembelajaran langsung berpusat pada pengajar (shyncronus e-learning) atau didesain untuk pembelajaran mandiri (ashyncronus e-learning). 5) membangun pemahaman dan ketrampilan yang terkait dengan tujuan pembelajaran baik secara perseorangan atau meningkatkan kinerja pembelajaran kelompok.

Dapat disimpulkan bahwa E-Learning adalah salah satu bentuk model pembelajaran yang memungkinkan tersampaikannya materi pembelajaran ke peserta didik dengan menggunakan media internet.

\section{Aplikasi Whatsapp}

Ningrum \& Pramonojati (2019) Whatsapp merupakan salah satu media sosial dengan kategori messenger/chatting yang memungkinkan penggunanya untuk mengirim pesan atau informasi secara pribadi maupun dalam suatu grup dengan berbagai fitur yang lebih user-friendly sehingga mudah digunakan oleh berbagai kalangan dari yang muda hingga yang tua, fitur-fitur tersebut meliputi chatting (teks, foto, video), panggilan telepon, video call, status whatsapp story yang lebih ringan dibandingkan dengan media sosial lainnya. Tujuan utama dari Whatsapp ini adalah untuk menggantikan fungsi SMS pada penggunaan biasa dengan mobile messenger antar platform yang bekerja 
dengan berbasis pada jaringan internet, maka dari itu, Whatsapp masih membutuhkan nomor telepon untuk bertukar pesan. Sedangkan Menurut Hadi dalam Sa'diyah (2019) Whatsapp adalah salah satu bagian dari smartphone yang digunakan dalam pembelajaran berbasis teknologi atau disebut dengan e-learning.

Menurut Rohmadi (2016) dalam bukunya yang berjudul tips produktif bersocial media, kriteria indikator penggunaan Whatsapp dibagi menjadi 6, yaitu : (1) Group Whatsapp yang bertujuan untuk reoni; (2) Group Whatsapp yang bertujuan untuk diskusi; (3) Mengirim undangan acara; (4) Untuk menelepon; (5) Untuk Berbagi lokasi; (6) Sebagai Whatsapp web.

Kelebihan Whatsapp yaitu : (1) tidak memerlukan uang untuk memasang aplikasi Whatsapp di telefon pintar dan biaya percuma.(2) Boleh berkomunikasi dengan lebih 50 0rang rekan dalam ruangan Grup.(3) Penggunaan data yang kecil berbanding aplikasi-aplikasi lain. Adapun Kekurangan Whatsapp yaitu (1) Tiada pilihan untuk daftar keluar. (2) Tidak boleh digunakan didalam computer atau laptop, hanya di telepon pintar saja (Rusni \& Lubis, 2017).

Menurut (Pustikayasa, 2019) kelebihan Whatsapp sebagai media pembelajaran adalah :

1. Group Whatsapp, pendidik dan peserta didik bisa bertanya jawab atau berdiskusi lebih rileks tanpa harus terpusat pada pendidik seperti pembelajaran di kelas, yang sering menimbulkan rasa takut salah dan malu pada peserta didik.

2. Dengan media Whatsapp, pendidik bisa berkreasi dalam memberikan materi maupun tugas tambahan kepada peserta didik.

3. Peserta didik bisa dengan mudah mengirim balik Prestasi pekerjaan, baik berupa komentar langsung (chat group), gambar, Video atau soft file lainnya yang berhubungan dengan pembelajaran,

4. Dengan media Whatsapp, metode pembelajaran menjadi ramah lingkungan karena tidak lagi menggunakan hardcopy (penggunaan kertas untuk mencetak atau menulis Prestasi pekerjaan peserta didik).

5. Dengan media Whatsapp, dapat menjadi salah satu solusi pendidik untuk menyampaikan materi tambahan sebagai bahan pembelajaran di luar kelas.

Menurut (Pustikayasa, 2019) kekurangan Whatsapp sebagai media pembelajaran adalah :

1. Pendidik dan peserta didik harus terhubung dengan layanan internet untuk mendapatkan informasi secara real times.

2. Komunikasi menggunakan video, gambar dan file yang berukuran besar berpengaruh pada penggunaan data (biaya).

3. Tanpa aturan atau kesepakatan yang jelas oleh admin (pendidik) grup, komunikasi dapat keluar dari konteks pembelajaran.

Dari uraian di atas bisa disimpulkan bahwa Whatsapp mempunyai banyak fitur seperti chatting (teks, foto, video), panggilan telepon, video call, status whatsapp story. Whatsapp juga masih membutuhkan nomor telepon untuk bertukar pesan. 


\section{Minat Belajar}

Menurut Susanto (2013) minat dapat diartikan sebagai suatu kesuksesan, kegemaran, atau kesenangan akan sesuatu. Dalam praktiknya, minat atau dorongan dalam diri peserta didik terkait dengan apa dan bagaimana peserta didik dapat mengaktualisasikan dirinya melalui belajar. Dimana identifikasi diri memiliki kaitan dengan peluang atau hambatan peserta didik dalam mengekspresikan potensi atau kreativitas dirinya sebagai perwujudan dari minat spesifik yang dia miliki. Adapun faktor keturunan dan pengaruh eksternal atau lingkungan lebih berkaitan dengan perubahan-perubahan yang terjadi dari minat peserta didik akibat dari pengaruh situasi kelas, sistem, dan dorongan keluarga. Sedangkan Minat belajar matematika adalah perasaan senang terhadap pelajaran matematika dimana seorang peserta didik menaruh perhatian yang besar terhadap matematika dan menjadikan pelajaran matematika pelajaran yang mudah (Siagian dalam Istianingsih, 2018).

Gagne dalam Susanto (2013) juga membedakan sebab timbulnya minat pada diri seseorang ada dua macam, yaitu minat spontan dan minat terpola. Minat spontan adalah minat yang muncul secara spontan dari dalam diri seseorang tanpa dipengaruhi oleh pihak luar. Minat terpola merupakan minat yang timbul karena terdapat pengaruh dari berbagai kegiatan yang terencana dan terpola, misalnya dalam kegiatan pembelajaran, baik di lembaga sekolah maupun diluar sekolah.

Dalam dunia pendidikan di sekolah, minat memegang peranan penting dalam belajar. Hal ini dikarenakan minat ini merupakan suatu kekuatan motivasi yang menyebabkan seseorang memusatkan perhatian terhadap seseorang, suatu benda, atau kegiatan tertentu. Dengan demikian, minat merupakan unsur yang menggerakkan motivasi seseorang sehingga orang tersebut dapat berkonsentrasi terhadap suatu benda atau kegiatan tertentu. Dengan adanya unsur minat belajar pada diri peserta didik, maka peserta didik akan memusatkan perhatiannya pada kegiatan belajar tersebut. Dengan demikian, minat merupakan faktor yang sangat penting untuk menunjang kegiatan belajar peserta didik. Kenyataan ini diperkuat oleh pendapat Sardiman, yang menyatakan bahwa proses belajar itu akan berjalan lancar kalau disertai dengan minat.

Dari beberapa definisi minat di atas, dapat disimpulkan bahwa minat belajar matematika merupakan dorongan dalam diri seseorang yang dapat menimbulkan ketertarikan terhadap pelajaran matematika..

\section{Prestasi Belajar}

Eliyah, dkk (2018) Prestasi belajar adalah hasil dari proses atau aktivitas sehingga menghasilkan sebuah perubahan dalam individu yaitu berupa nilai. Sedangkan menurut Istiarni (2013) prestasi belajar adalah ukuran keberhasilan kegiatan belajar peserta didik dalam menguasai sejumlah mata pelajaran selama periode tertentu.

Dengan demikian dapat disimpulkan bahwa prestasi belajar adalah hasil dari proses belajar sehingga menghasilkan keberhasilan dalam sejumlah mata pelajaran selama priode tertentu.

\section{METODE PENELITIAN Jenis Penelitian}

Jenis penelitian ini adalah eksperimem dengan pendekatan kuantitatif 
dan desain penelitian yang digunakan adalah desain intact- Group Comparison

\section{Waktu dan Tempat Penelitian}

Penelitian dilakukan pada tanggal 11 mei 2020 sampai dengan 14 mei 2020 selama 4 kali pertemuan berturut-turut karena dengan adanya pandemi corona virus-19 pihak sekolah meminta agar penelitian diadakan secepatnya agar peserta didik tidak terbebani. Dengan pokok bahasan trigonometri di SMK Negeri 2 Slawi.

\section{Subjek Penelitian}

Populasi dalam penelitian ini yaitu seluruh peserta didik kelas $\mathrm{X}$ TKRO Semester genap SMK N 2 Slawi tahun pelajaran 2019/2020 yang terdiri dari 3 kelas yang berjumlah 99 peserta didik. Teknik pengampilan sampel penelitian ini adalah cluster random sampling, dari 3 kelas dipilih 2 kelas untuk dijadikan sampel, yaitu kelas X TKRO 1 sebagai kelas Eksperimen dan kelas X TKRO 1 sebagai kelas kontrol.

\section{Prosedur}

Pembelajaran menggunakan aplikasi Whatsapp dilakukan pada pokok bahasan Trigonometri. Pada proses pembelajaran guru memberikan materi melalui video pembelajaran dan materi berupa file word dikelas eksperimen sedangkan untuk dikelas kontrol peserta didik hanya diberikan tugas-tugas saja tanpa diberikan materi oleh guru karena di sekolah tersebut seringkali hanya diberikan tugas-tugas saja dan hanya diperintahkan membaca dan memahami materi sendiri yang ada dibuku paket yang dipinjami oleh sekolah. Penggunaan aplikasi Whatsapp dilakukan untuk mengetahui minat dan Prestasi belajar peserta didik. Pada akhir penelitian peserta didik diminta untuk mengisi angket minat belajar dan tes Prestasi belajar dalam bentuk pilihan ganda untuk mengetahui minat dan prestasi peserta didik.

\section{Data, Intrumen, dan Teknik Pengumpulan Data}

Instrumen yang digunakan dalam penelitian ini yaitu instrumen angket dan instrumen tes. Instrumen angket yang digunakan adalah 20 item angket dan Instrumen tes yang digunakan adalah 10 soal berbentuk pilihan ganda.Validitas angket dan tes dalam penelitian ini yaitu tidak menggunakan analisis hitung tetapi dengan meminta pertimbangan pakar (expert judgment).

Teknik pengumpulan data penelitian ini menggunakan teknik wawancara, dokumentasi, angket dan tes. Wawancara digunakan untuk mendapatkan informasi tentang proses pembelajaran matematika, dan Prestasi belajar peserta didik kelas X TKRO SMK N 2 Slawi untuk mengetahui data kondisi awal peserta didik. Dokumentasi digunakan untuk mendapatkan data-data peserta didik. Angket digunakan untuk mencari data minat belajar peserta didik dan Tes digunakan untuk mencari data Prestasi belajar peserta didik.

\section{Teknik Analisis Data}

Teknik analisis data penelitian ini dalam pengujian hipotesis menggunakan uji $\tau^{2}$-hotelling dengan bantuan software SPSS. Dengan terlebih dahulu data diuji menggunakan uji liliefor dan Bartlett serta uji Box's M untuk mengetahui normalitas dan homogenitas data. Uji $\tau^{2}$-hotelling digunakan untuk menguji apakah minat dan prestasi belajar peserta didik lebih baik. 


\section{HASIL PENELITIAN DAN PEMBAHASAN}

\section{Hasil Penelitian}

Penelitian ini dilakukan di SMK Negeri 2 Slawi dengan tujuan untuk mengkaji Minat dan Prestasi belajar matematika peserta didik yang diajar menggunakan aplikasi Whatsapp dengan materi lebih baik daripada peserta didik yang diajar menggunakan aplikasi Whatsapp tanpa materi. Data penelitian ini diperoleh dari hasil uji hipotesis dan pembahasan hasil penelitian.

Sebelum memberikan perlakuan kepada kelas eksperimen dan kelas kontrol , dilakukan uji prasyarat sebelum penelitian yang meliputi uji normalitas dengan hasil perhitungan $\mathrm{L}_{\text {0maks }}=0.1089$ dan $\mathrm{L}_{\text {tabel }(0.05)}=$ 0.1099 karena $\mathrm{L}_{\text {0maks }}<\mathrm{L}_{\text {tabel }}$ maka $\mathrm{H} 0$ diterima yang artinya data berdistribusi normal , uji homogenitas dengan hasil yang diperoleh $X_{\text {hitung }}^{2}=3.373$ dan $X_{\text {tabel (0.05) }}^{2}=$ 3.841 karena $X_{\text {hitung }}^{2}<X_{\text {tabel }}^{2}$ maka $\mathrm{H}_{0}$ diterima yang artinya sampel berasal dari populasi yang mempunyai keragaman homogeny, dan uji kesetaraan sampel dengan hasil perhitungan $\mathrm{F}_{\text {hitung }}=0.0381$ dan $\mathrm{F}_{\text {tabel(0.05) }}=3.145$ karena $\mathrm{F}_{\text {hitung }}<\mathrm{F}_{\text {tabel }}$ maka Ho diterima dengan kata lain tidak ada perbedaan rata-rata hasil belajar matematika antara kelas eksperimen dan kelas kontrol. Data yang digunakan yaitu nilai Penilaian Tengah Semester (PTS) semester genap tahun pelajaran 2019/2020. Hasil analisis menyatakan tidak ada perbedaan antara kelas eksperimen dan kelas kontrol.

Data minat belajar diperoleh dari skor angket berbentuk pilihan ganda yang berjumlah 20 item dan Prestasi belajar diperoleh dari nilai tes berbentuk pilihan ganda yang berjumlah 10 soal dengan pokok bahasan Trigonometri. Tes ini diberikan kepada peserta didik kelas X TKRO SMK Negeri 2 Slawi yang terpilih sebagai kelas eksperimen dan kelas kontrol. Data diperoleh setelah peserta didik mendapat perlakuan. Hasil perhitungan dapat dilihat pada tabel 1 .

Tabel 1. Hasil Analisis Perhitungan Tes Minat Belajar Dan Prestasi Belajar Dengan Uji $\tau^{2}$-Hotelling

\begin{tabular}{ccccc}
\hline No & Variabel & $\boldsymbol{\tau}^{2}$-Hotelling & Tabel $\boldsymbol{\tau}^{2}$-Hotelling & Kesimpulan \\
\hline 1 & Minat dan & 13.2317 & 6.350 & Ho Ditolak \\
& Prestasi Belajar & & & \\
\hline
\end{tabular}

Berdasarkan hasil perhitungan menggunakan $\tau^{2}$-Hotelling untuk minat dan Prestasi belajar diperoleh $\tau^{2}$-Hotelling $=$ 13.2317 dan tabel $\tau^{2}$-Hotelling $=6.350$ dengan taraf signifikasi 5\%. Karena $\tau^{2}$ Hotelling $>$ tabel $\tau^{2}$-Hotelling maka Ho ditolak sehingga dapat dikatakan minat dan Prestasi belajar peserta didik yang diajar menggunakan aplikasi Whatsapp dengan materi lebih baik daripada peserta didik yang diajar menggunakan aplikasi Whatsapp tanpa materi.

\section{Pembahasan}

Berdasarkan hasil penelitian yang dilakukan di SMK N 2 Slawi pada peserta didik kelas $\mathrm{X}$ semester genap tahun ajaran 2019/2020 pada materi aturan sinus, aturan cosinus, dan luas segitiga dalam trigonometri menunjukan bahwa minat 
belajar matematika peserta didik yang diajar dengan aplikasi Whatsapp dengan materi menujukkan hasil yang tinggi, hal ini karena dalam pembelajaran menggunakan aplikasi Whatsapp dengan materi peserta didik diajarkan bekerjasama dengan teman lainnya untuk berperan aktif sebagai tutor sebaya karena didalam pembelajaran menggunakan grup Whatsapp ada beberapa anak yang tidak aktif dalam grup Whatsapp.

Pembelajaran di kelas eksperimen menggunakan aplikasi Whatsapp dengan materi. Pelaksanaan pembelajaran dimulai dengan menyampaikan tujuan pembelajaran yang akan dicapai peserta didik dan menyiapkan tugas peserta didik serta memberikan motivasi untuk mengikuti proses pembelajaran. Kemudian guru memberikan materi pembelajaran melalui video pembelajaran, dengan video pembelajaran peserta didik lebih tertarik sehingga minat dan prestasi belajar peserta didik lebih baik.

Uji $\tau^{2}$-Hotelling diperoleh bahwa pembelajaran menggunakan aplikasi Whatsapp dengan materi lebih baik daripada peserta didik yang diajar menggunakan aplikasi Whatsapp tanpa materi terhadap minat dan prestasi belajar matematika peserta didik. Hasil penelitian Nisa (2012) menyatakan bahwa rata-rata hasil belajar mata kuliah statistik mahasiswa Tad-ris Bahasa Inggris semester II tahun 2010/2011 yang diajar metode elearning lebih baik daripada rata-rata hasil belajar mahasiswa yang diajar dengan metode konvensional. Selain itu Ahmad Nu'man (2014) didapatkan hasil bahwa efektivitas penggunaan media pembelajaran E-learning berbasis edmodo lebih tinggi daripada menggunakan media pembelajaran konvensional.
Pembelajaran menggunakan aplikasi Whatsapp dilakukan di SMK N 2 Slawi dikarenakan adanya pandemi Covid19, pemerintah memberlakukan pembelajaran jarak jauh (PJJ) di semua sekolah yang ada di Indonesia. Salah satu hal penting dalam merencanakan suatu pembelajaran didalam masa pandemi covid-19 seperti ini adalah pemilihan suatu media pembelajaran yang tepat agar dapat lebih meningkatkan minat belajar peserta didik maupun meningkatkan prestasi belajar peserta didik. Seperti terlihat bahwa rata- rata peserta didik yang diajar menggunakan aplikasi Whatsapp dengan materi lebih baik daripada peserta didik yang diajar menggunakan aplikasi Whatsapp tanpa materi.

\section{SIMPULAN DAN SARAN \\ Simpulan}

Berdasarkan hasil penelitian dan analisis data yang telah diperoleh, dapat disimpulkan bahwa Pembelajaran menggunakan aplikasi Whatsapp dengan materi lebih baik daripada pembelajaran menggunakan aplikasi Whatsapp tanpa materi terhadap minat dan prestasi belajar peserta didik.

\section{Saran}

Hendaknya Guru menyimpan jawaban peserta didik dan peserta didik menyimpan materi terlebih dahulu yang dikirimkan oleh guru supaya pesan yang dikirim guru tidak tenggelam oleh pesan yang baru.

\section{DAFTAR PUSTAKA}

Clark, R.C \& Mayer, R.E. (2008). Elearning and the science of indtruction: proven guidelinesfor consumer and designers of 
multimedia learning, second edition. San Fransisco: John Wiley \& Sons, Inc.

Eliyah, S., isnani, I., utami, w. B. (2018). Keefektifan model pembelajaran course review horay berbantuan power point terhadap kepercayaan diri dan prestasi belajar. Jurnal edukasi dan sains matematika (JESMAT), 4 (2), 131-140.

Hanum, N. S. (2013). Keefektifan elearning sebagai media pembelajaran (studi evaluasi model pembelajaran elearning SMK Telkom Sandhy Putra Purwokerto). Jurnal Pendidikan Vokasi, 3(1).

Istianingsih, K., \& Mir'anina, R. (2018). Pengaruh Model Two Stay Two Stray dengan Aktivitas Window Shoping Terhadap Minat dan Hasil Belajar Siswa MTS Al-Muttaqin Plemahan Kediri. JIPMat, 3(2).

Istiarni, A. (2013). Penerapan Syndicate Group Dalam Upaya Meningkatkan Prestasi Belajar Matematika Peserta Didik Kelas VIII-A Di SMP Negeri 1 Kutowinangun. Ekuivalen Pendidikan Matematika, Vol 1 No. 1.

Mulyati, M. (2017). Pengaruh Kualitas Sistem Dan Informasi Pada Sistem Informasi Pembelajaran Online Terhadap Minat Pengguna Dan Peggunaan Sistem (Studi Kasus: Simponi AMIK MDP, STMIK GI MDP DAN STIE MDP). Jurnal TAM (Technology Acceptance Model), 8(2), 90-100.

Ningrum,N. A. P., \& Pramonojati, T.A. (2019).Pengaruh Penggunaan Aplikasi Whatsapp Terhadap Efektivitas Komunikasi Organisasi Di Lingkungan Pegawai Dinas Pariwisata Diy. eProceedings of Management, 6(1).

Nisa, L. C. (2002). Pengaruh Pembelajarane-Learning Terhadap Hasil Belajar Mata Kuliah Statistics Mahasiswa Tadris Bahasa Inggris
Fakultas Tarbiyah IAIN Walisongo. Jurnal Phenomenon, 2(1), 7-26.

Nu'man, A. Z. (2014). Efektivitas Penerapan E-Learning Model Edmodo Dalam Pembelajaran Pendidikan Agama Islam terhadap Hasili Belajar Siswa (Studi Kasus: Smk Muhammadiyah 1 Sukoharjo). Duta Com Journal, 7(1).

Pustikayasa, I. M. (2019). Grup Whatsapp Sebagai Media Pembelajaran. Widya Genitri. Jurnal Ilmiah Pendidikan. Agama Dan Kebudayaan Hindu, 10(2), 53-62.

Rohmadi, A. (2016). Tips Produktif Bersocial Media. Jakarta: Pt Elex Media Komputindo Kompas Gramedia Building.

Rusni, A., \& Lubis, E. E. (2017). Penggunaan Media Online Whatsapp Dalam Aktivitas Komunitas One Day Onr Juz (odoj) Dalam Meningkatkan Minat Tilawah Odojer Di Kota Pekanbaru (doctoral dissertation, Riau University).

Sa'diyah, H. (2019). Upaya menumbuhkan self-confidence berbicara bahasa Arab mahasiswa melalui grup Whatsapp. Al-miyar,2(2), 149-164

Siagian, R. E. F. (2015). Pengaruh minat dan kebiasaan belajar peserta didik terrhadap prestasi belajar matematika. Formatif: Jurnal Ilmiah Pendidikan MIPA, 2(2).

Slameto. (2010). Belajar dan FaktorFaktor Yang Mempengaruhi. Jakarta: Rineka Cipta.

Susanto, A. (2013). Teori Belajar Dan Pembelajaran di Sekolah Dasar. Jakarta: Kencana Prenada Media Group.

Syah, M. (2006). Psikologi Belajar. Jakarta: PT Raja Grapindo Persada.

Utomo, S. W., Ubaidillah, M., Aeni, W. A., Yusupa, A., Warsihna, J., Suparti, N. \& Salim, A. (2018). Pemanfaatan Aplikasi Whatsapp pada Pembelajaran Berbasis Masalah untuk Mata Kuliah Akuntansi 
Internasional di Universitas PGRI

Madiun. Kwangsa Jurnal teknologi

Pendidikan. 6(2), 199-211. 